\title{
Angles
}

New Perspectives on the Anglophone World

$6 \mid 2018$

Experimental Art

\section{A work of art as an experimental exhibit. Broodthaers and the Eagle}

\section{Susanne König}

\section{Q OpenEdition \\ 1 Journals}

\section{Electronic version}

URL: https://journals.openedition.org/angles/1050

DOI: $10.4000 /$ angles. 1050

ISSN: 2274-2042

\section{Publisher}

Société des Anglicistes de l'Enseignement Supérieur

\section{Electronic reference}

Susanne König, "A work of art as an experimental exhibit. Broodthaers and the Eagle", Angles [Online], 6 | 2018, Online since 01 April 2018, connection on 06 June 2022. URL: http:// journals.openedition.org/angles/1050 ; DOI: https://doi.org/10.4000/angles.1050

This text was automatically generated on 6 June 2022.

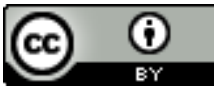

Angles est mise à disposition selon les termes de la Licence Creative Commons Attribution 4.0 International. 


\title{
A work of art as an experimental exhibit. Broodthaers and the Eagle
}

\author{
Susanne König
}

Experimentation is integral to literature and art as well as to the natural sciences. The search for new artistic means of expression, the formation of a new canon and the use of new artistic materials are all based on findings obtained through experimentation. Experimentation was a key category for the modernists in particular (Dingler 1928). The difference from previous periods lay especially in the modernists having given a new programmatic significance to experimental procedures in both the natural sciences and art. The modernists were distinguished by a stylistic pluralism as an expression of a constantly changing society, accompanied by a new understanding of art. In particular, art after 1945 gave rise to a new concept of art hardly anticipated in the traditional genres of painting and sculpture, for example.

But what does "experiment" mean? While the Scholastics understood "experiment" to mean experience in general, the modern era restricted its relevant sense to experience brought about through deliberate human action (Dingler 1928). Thus "experimentation" nowadays refers to controlled, purposive action aiming at some specific goal: the invention of something new or the production of new knowledge. This quest for the new characterises modern art and in particular contemporary art in a variety of ways. While controlled artistic practices may at first glance seem to conflict with the artist's claim to freedom, artists do indeed seek new practices that are repeatable and therefore controllable (Rheinberger 2012).

3 In his classic study, The Story of Art, Ernst Gombrich (1909-2001) thus entitled his chapter on Modernism "Experimental Art", to underscore the newness of this age (Gombrich 1984: 557-598). While previous forms of art built upon the stylistic features of past eras, modifying them or combining them, the modernists distinctively chose wholly new preconditions and developed new methods, materials and content. Gombrich applied the concept of experiment only to art of the first half of the $20^{\text {th }}$ century, however. But what role has experiment played in post-war art? While the experimental character of post-war art seems to have greatly intensified, describing 
every new artistic method as "experimental" would be to water down the concept. Not everything that is contemporary is also experimental. "Experimental" does not just refer to something new - experimental art rather comes from certain experimental methods.

In his work Musée d'Art Moderne, Département des Aigles (1968-72) Belgian artist and poet Marcel Broodthaers investigates a particular form of experimental art. Broodthaers' fictional museum project provides a good basis for a study of the concept, as the artist has himself repeatedly referred to the experimental quality of his art. Indeed, our starting assumption in this essay is that this work by Broodthaers illustrates in a quite paradigmatic way central elements of experimentation in contemporary art of the 1960s and 70s. For example, on 16 May 1972 Broodthaers opened a section of a museum entitled The Eagle from the Oligocene to the Present in the Städtischer Kunsthalle in Düsseldorf, signing it with the following words: "Marcel Broodthaers shows an experimental exhibition of his Musée d'Art Moderne, Département des Aigles, Section des Figures" (Broodthaers 1972, I and II).

The Düsseldorf exhibition is part of his fictional museum project, which extended over a four-year period from 1968 to $1972 .{ }^{1}$ Altogether it comprised twelve sections appearing for varying periods of time in different places. The content of the project concerned the relationship between art and society and examined the definition of art as a social convention. The related analysis of art and the art world is then not to be separated from the museum as an institution, which after all is the place where the social conceptions of art manifest themselves. In this project, Broodthaers treated the institutional environment with its recurring exhibition situations, its mechanisms of conveying art and its structure. Given the displacement in space and time, Broodthaers's museum never had the form of an integral "building", however. The displacement of an art object over such a long period of time and through such an expanse of space underscores the experimental nature of the project, for hardly has any one visitor seen the complete museum with its twelve sections. The first part of this article examines the experiment in which a museum with twelve sections altogether is declared to be a work of art. The second part then explicates the experiment in which an exhibition is declared to be a work of art. Finally, the third part examines the role of the viewer within Broodthaers' artistic experiment.

\section{Experiment 1: The museum as a work of art}

Broodthaers founded the Musée d'Art Moderne, Département des Aigles, Section XIXème Siècle, in his Brussels atelier on 27 September 1968. In the three nearly empty rooms of the museum, which existed for one year, he exhibited packaging material on loan from Continental Menkes, an art transport company. The approximately fifty crates of varying sizes bore labels printed in English or French, all of which referred to art: "Picture", "Tableau", "Sculpture", "Handle with care", "Keep dry", "Brussels", "Painting", "Fragile", "Haut", "Bas" and so on. To this collection Broodthaers added around fifty postcards showing paintings and drawings from French masters of the $19^{\text {th }}$ century (Broodthaers 1991: 194-5; Crimp 1996: 221; Broodthaers 1994: 46-50).

7 Supplementing this ensemble were two slide shows with caricatures as well as postcards of $19^{\text {th }}$ century paintings and drawings. These reproductions lent the section its name, Section XIXème Siècle. This very first exhibition exemplified the experimental 
character of this work, for in lieu of a conventional work of art, Broodthaers made the context in which artistic activity takes place the subject of his artistic-analytic inquiry. His art became the instrument of criticism and analysis of the institution of art and its social functions. The question of the extent to which museums participate in defining art itself arose when Broodthaers extended the 1960s student movement's general criticism of institutions to the realm of art. In doing so, he chose a moderate form of analysis that viewed the institutions from the inside, in keeping with German activist Rudi Dutschke's call to "March through the institutions". Dutschke had the idea of changing society by working from or within the institutions. This march into and within the institutions can also be seen in the course of the fictional museum project from 1968 through 1972.

This artistic-analytic method has an experimental character if the medium of art, its institutions and its own system become the subject of art. While the general criticism of institutions by the student movement of the 1960s was a widespread phenomenon in the Western World, the extension to the artistic realm was a novelty at the time. One of the greatest challenges of this experiment for Broodthaers, however, was whether the viewer would recognise the fictional museum as art and discern the underlying analysis of art.

Broodthaers therefore originally abandoned the institutional place of the museum in order to analyse, within the private space of his atelier, the conditions of the place he had just left - namely the museum with its specific relationship between art and society. From this marginal position he endeavoured to reflect on art as a system, moving from section to section and back into the field of art until, arriving at the centre, namely at the most important exhibition for contemporary art, the documenta, he concluded his inquiry. His next two sections thus disclosed two unusual spaces of art, namely writing in the Section Litter raire and the beach and sea in the Section Documentaire (Broodthaers 2003: 48). The Section Littéraire comprised a series of open letters written by Broodthaers between 1968 and 1971. As he has never mentioned, exhibited or published all the letters in their totality, however, we cannot say with certainty which individual letters belong to the Section Littéraire. In this section Broodthaers experimented with new places for exhibiting and with writing as an artistic medium.

The Section Documentaire was created on a summer day in 1969, in the coastal village of Le Coq in Belgium. Together with his friend Herman Daled, Broodthaers dug and etched the ground plan of a museum in the sand still moist at ebb tide, surrounded by curious beachgoers. To clarify their idea, Broodthaers placed signs along the boundaries of the ground plan with directions and prohibitions in the Belgian national languages of French and Flemish generally familiar to museum-goers. For example, one sign read "Musée d'Art Moderne, Section XIXème Siècle", another "Défense absolue de toucher aux objets" ("Touching the objects is strictly forbidden") and still another "Il est strictement interdit de circuler sur les travaux" ("Treading on the objects is strictly forbidden") (Broodthaers 1991: 204). Once their project was completed, Broodthaers' wife Maria Gilissen photographed the scene before the tide came in and washed it away just a few hours later. The section owes its name to these photographs. Here Broodthaers again experimented with new exhibition locations and with the documentation as a new medium of art. 
11 Exactly one year after the opening of the first Section XIXème Siècle in Brussels on 29 September 1969, Broodthaers closed the section. To the closing ceremony he invited guests whom he had brought along with the Brussels exhibition to Antwerp for the A379089 alternative art centre (Broodthaers 1992: 201-3). Here he replaced the $19^{\text {th }}$ century postcards with postcards of paintings by a $17^{\text {th }}$ century master, Peter Paul Rubens. The A379089 alternative art centre generally exhibited no classical works of art, but merely works which, like Broodthaers's, experimented with new media and materials or belonged to an extended artistic discourse.

12 From there, Broodthaers's museum assumed the unconventional exhibition status of an urban institution. He exhibited the Section XIXème Siècle (Bis) in the between series at the Düsseldorf Städtischer Kunsthalle, which since 1968 had taken place in irregular succession between the official exhibitions (Broodthaers 1997: 74-7). For the new section, Broodthaers borrowed eight original works of the $19^{\text {th }}$ century Düsseldorf School of Painting from the repository of the Düsseldorf art museum and hung them in the typical manner of a $19^{\text {th }}$ century gallery: two rows of four paintings (Broodthaers 1992: 206). The between series was also experimental in character: as usually the time between exhibitions is used for dismantling and setting up and for conducting yet another exhibition series (Buschmann 202: 143). Jürgen Hartan, the director at the time, nevertheless used between for art forms deviating from customary notions about art. Paradoxically, Broodthaers nevertheless presented eight original works from the $19^{\text {th }}$ century as a sort of "repeat exhibition" of the first section.

The Section Folkorique gained entry to institutional space in 1970, when Broodthaers donated a work from his own collection to the curator of the Département Folklorique of the Zeeuws Museum in Middelburg, Piet Van Daalen, namely a cloth embroidered with the words "Musée - Museum, les Aigles (the Eagles)", fabricated by his daughter Marie-Puck (Zwirner 1997: 123). The donation of the folkloristic needlework was to be only part of the Section Folklorique. The project was to be completed by a book or catalogue with illustrations of the Département Folklorique works, photographed by Maria Gilissen. From these photographs Broodthaers and Piet Van Daalen intended to select a series. The edition was never completed, however (Broodthaers 1992: 205).

On 12 January 1971 Broodthaers opened the Section Cinéma in a basement room at Burgplatz 12 in Düsseldorf (Broodthaers 1997: 140-169). Here Broodthaers showed his films and also experimented with new forms of presentation. The basement walls were partly painted black and white (Broodthaers 1997: 140-161). On one wall he installed two projection surfaces next to each other. One presented a political map of the world, on which he projected the film Le Musée et la Discussion (1969) (Broodthaers 1997: 80). For the other, he painted a white projection area on a black wall, and on top of that several black rectangles in which "Fig. 12", "Fig. 2", "Fig. 1" and "Fig. A" were inscribed in white. When Broodthaers showed videos on the painted and printed projection surfaces, visitors found themselves partially unable to distinguish between film and surface. In his Section Cinéma Broodthaers seemed to have returned to the marginal areas of art. This impression was primarily due to film not yet having played a major role in the contemporary art of the time, however.

At the 1971 Art Cologne fair Broodthaers then exhibited his Section Financière at the Michael Werner Gallery stand. Paradoxically, however, the Musée d'Art Moderne was for sale here between 1970 and 1971 as it had gone bankrupt. Broodthaers drafted the cover artwork for 19 copies of the art market catalogue. The front cover bore the title 
“Section Financière, Musée d'Art Moderne à vendre 1970-71 pour cause de faillite" ("Financial section, Museum of Modern Art, for sale 1970 - 1971 on account of bankruptcy"). The back cover showed an eagle with the lettering 'Fig. 0' and the text "O Mélancolie, aigre château des Aigles" ("Oh, Melancholia, sour château of the eagles") (Broodthaers 1992: 212-3).With this section at the Art Cologne fair, Broodthaers began occupying an increasingly important institution in art, and he began focussing on its commercialisation.

Figure 1: Marcel Broodthaers, Musée d'Art Moderne à vendre - pour cause de faillite (Museum of Modern Art for sale - due to bankruptcy), 1970-71

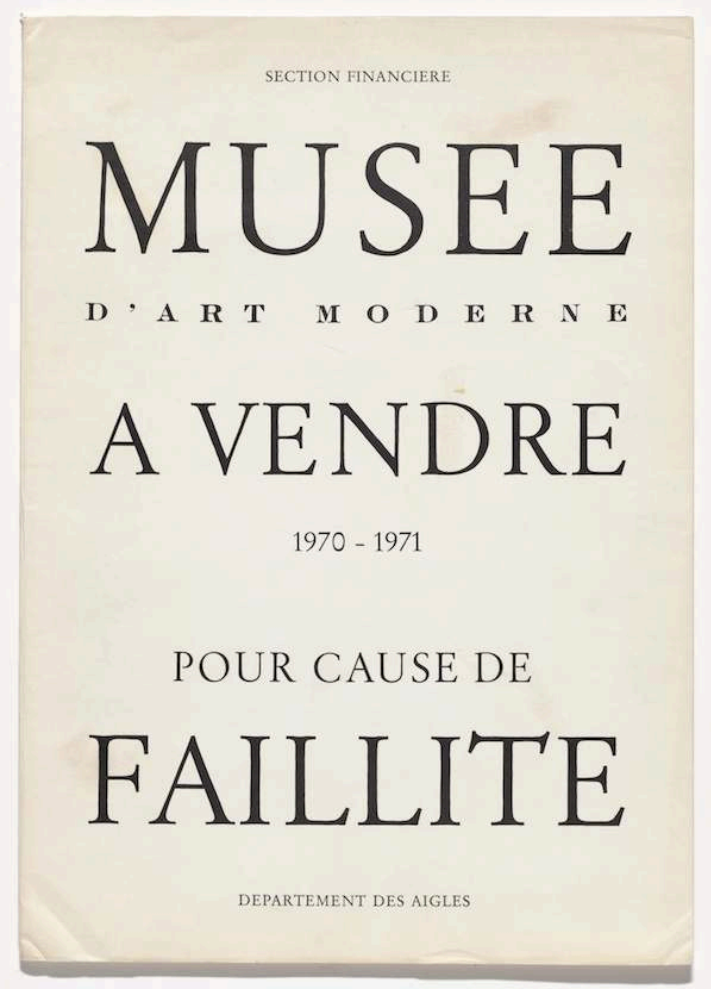

(c) 2016 Estate of Marcel Broodthaers / Artists Rights Society (ARS), New York / SABAM, Brussels. Source: https://www.moma.org/slideshows/45/8

With the last four museum sections Broodthaers then moved into the centre of the art world. Featured as a conventional exhibition at the Düsseldorf Kunsthalle, his Section des Figures totally dissolved the visible demarcation from his museum fiction (Der Adler 1972, I and II; Borgemeister 1977: 135-154; König 2012: 35-46). His exhibition entitled The Eagle from the Oligocene to the Present presented the fictional museum as an ordinary exhibition. Here he exhibited different objects of art in addition to items of natural history, handicraft, advertising and mundane use whose only unifying element was the eagle motif. The Section des Figures was the visualisation of the Département des Aigles. The objects were appended with text panels recalling title labels and bearing the sentence: "This is not a work of art".

The final three sections were shown at the documenta 5 in Kassel. The Section Publicité concerned the publicity work and advertising conducted by museums, while at the same time promoting the Section des Figures concurrently running at the Düsseldorf 
Kunsthalle (Buchloch and Gilissen 1995). Broodthaers thus clothed an affirmative selfpromotion as a reflection on the relationship between advertising and art.

The last two sections shared a place at the documenta. After 50 days, Broodthaers transformed the Musée d'Art Moderne, Département des Aigles, Section Moderne, into the Musée d'Art Ancien, Département des Aigles, Galerie du XXème Siècle, and thereby developed the autonomous museum for $20^{\text {th }}$ century art into a traditional museum with a section for modern art (Broodthaers 1995: 68-79). Museums of modern art were still not very common at the time.

Broodthaers' Musée d'Art Moderne follows the tradition of Marcel Duchamp's readymades. Duchamp examined the alleged phenomenon of making an object a work of art by declaring it to be such. In taking up this tradition, Broodthaers also asked whether a museum could itself be declared a work of art. Broodthaers was particularly interested in whether the viewer could recognise a museum as a work of art if it was not an actual "building", but rather an exhibition extending over a four-year period in different places and employing the most variegated materials, signs and allusions. Within this museum, he examined the various sections ( $17^{\text {th }}$ and $19^{\text {th }}$ centuries, for example) and their tasks and functions (collecting, preserving, exhibiting, public relations). In doing so, he employed artistic materials still unusual at that time, while also studying contemporary artistic styles, thus approaching Land Art through the use of sand and Language Art through the use of writing.

\section{Experiment 2: The exhibition as a work of art}

Broodthaers himself articulated the purpose of the fictional museum as the "analytical study of the concept of art" (Broodthaers 1972, I: 4). This treatment did not pertain to such pictorial issues as style, composition or materiality, however, but rather elaborated on the contextual conditions of art. Within the museum cycle, the Section des Figures and its exhibition entitled The Eagle from the Oligocene to the Present assumed a key position, as they embodied the overall idea of the fictional museum. While the other sections referred to the museum through quotations and allusions, the Section des Figures dissolved the boundaries between reality and fiction so that the exhibition visitor could barely distinguish the fictional museum and the actual exhibition.

The intention and strategy of the exhibition are evident from the subtitle itself, The Eagle from the Oligocene to the Present - the Oligocene being the middle part of the tertiary period that began 65 million years ago and ended 2.5 million years ago and during which the eagle evolved: the implied criticism of the scientific principles of classification dissolve the boundaries of traditional scientific and artistic disciplines, as Jürgen Harten also makes clear in the exhibition catalogue. Harten remarks that "an area [has been] outlined that heretofore has resisted scientific treatment because it could not be confined to any one discipline" (Broodthaers 1972, I: 9). The symbolic overloading of the eagle is exposed through the ironic exaltation of the same and the ironic treatment of scientific authority, as Broodthaers expressly points out in the catalogue: "But the geology should be incorporated in the (sensational) title, giving the title a flair of pseudo-scholarship and exposing the eagle symbol as something adopted without reflection, as not even put up for discussion" (Broodthaers 1972, II: 18). The "unreflective" use of the eagle symbol refers both to the ideologically, religiously or politically motivated object and to the art object itself. 

European cultural history. As Broodthaers remarks, scientific investigations into the "king of the air" contributed to this symbolism by "developing 監 ... 国 an erroneous idea of the bird. Most scientific writers described the eagle in pathetic terms" (Broodthaers 1972, II: 18). In other words, the eagle became the myth par excellence. In this exhibition Broodthaers thus dealt with the eagle, its image and name and with its different sorts of significance. We see this first in his choice of exhibits, displaying originals alongside copies, prints, photographs or commodities (Broodthaers 1972, II: 18). Besides their motivic equality, the objects also shared the status of acknowledged museum objects: many of them had already been legitimated as art objects by their original museums, whereas the others, "non-museum" objects, were thus upgraded only in Broodthaers's fictional museum. lending institutions, given the absence of any system underlying the collection. According to Harten, the exhibition did not aim at any completeness, its scope being determined solely by "arbitrary bits of knowledge and the lenders' willingness to help" (Broodthaers 1972, I: 18). The materiality of the exhibits of was also coincidental, as the lenders did not always send the originals, but sometimes only copies or photographs of the objects. ${ }^{2}$

The arbitrarily assembled objects, each with a different temporal and geographical origin, had a dual significance in the exhibition: on the one hand as valuable museumlike artefacts and on the other hand as mythological symbols. Michael Oppitz describes these two levels in these terms:

On the one hand, because they are being shown as museum pieces, and on the other hand because they are signs already carrying cultural baggage: wherever encountered, the image of the eagle is highly emblematic and mythologically significant. The eagle can represent strength, virility, severity, eschatological yearning, freedom or domination. In other words, the eagles presented by Broodthaers all move on the $2^{\text {nd }}$ level... and precisely in showing this to us, Broodthaers returns the eagles to the object language level. (Broodthaers 1972, II: 18)

Oppitz highlights the multiple coding of the eagle and stresses that by juxtaposing the different objects Broodthaers undoes the charged character of their content. Broodthaers's treatment of the exhibits described above gave their positioning in the exhibition a particular significance, revealing fundamental shifts in the traditional classification systems of museums: the exhibits are positioned only according to the requirements and possibilities of their presentation, and not by chronological or geographical order. As a result, viewers could no longer follow a specified route through the exhibition, but had to make their own way (Broodthaers 1972, II: 20). At the same time, large chronological and geographical jumps between the individual exhibits occurred, which was also in keeping with the overall concept. While the exhibits all shared the same motif, they differed in their categorical references. Displayed side by side, they afforded the viewer new possibilities of combination that would not have been available to a visitor to the corresponding home collections. Conventional museums operate according to classification schemes that internally organise the exhibits either in chronological terms or by individual section and externally subdivide the types of museum into categories like art, military or archaeology (Minges 1998). In Broodthaers's case, on the other hand, the exhibits are 
removed from this system and recombined on the basis of their shared motif (Borgemeister 1977: 146).

feared that his museum might be misunderstood by viewers as a sort of "opinion". To counteract this inclination, he tried to debunk traditional academic category systems as the site of an only seemingly objective production of consensus. The traditional museum, whose concept arose from the modern encyclopaedic systemisation of knowledge, collects objects, conducts inventories, runs exhibitions and publishes catalogues. Inventories tear the objects from their historical contexts, isolate them as individual items and turn them into artistic artefacts to be re-assigned a place in accordance with conventional stipulations. They then become objects of a certain system of knowledge (Borgemeister 1977: 147). Broodthaers's method splits the eagle into its images on the one hand and their significances on the other: these significances are lexically stored and the object preserved as an "aesthetic preparation" in the museum (Broodthaers 1972, II: 10). In the context of his deconstructive project, he now provisionally endows all the exhibited objects with the status of "work of art" expressly including those which previously no museum had elevated to this status in any exhibition. In his view, isolating the objects entails their aestheticisation, which is of only short duration in the fictional museum, however.

28 Conventional museums turn objects into representatives of an idea of art that overly emphasises aesthetic impressions, while at the same time suppressing reflection on the social, political or economic context. The eagle items were ideal for elaborating this view, for they combined two sorts of myths: first of all, the eagle is an animal with certain ascribed qualities whose image always confronts the addressee with an overload of symbolism that can hardly be suppressed. Secondly, the image of the eagle is an aesthetic artefact, embodying a museum-governed idea of art. Broodthaers thus writes that the "concept of the exhibition rests on the identity of the eagle as idea with art as idea" (Broodthaers 1972, II: 19).

This commonality between art as idea and the eagle as idea lies in the comparability and interchangeability of the two. According to André Malraux (1956: 9-12), the peculiar character of museums lies in their practice of comparing and exchanging works of art with one another, a function corresponding to the basic significance of the eagle objects in Broodthaers's museum, where they too are compared and interchanged with one another. The museum makes the artworks representatives of its own ideological idea, an unspoken, abstract idea of art. The objects are thus robbed of their inherent value in terms of their history, geography or moral function, for example, as Borgemeister notes: "It [the museum] does this in order to subsume under a concept that is at once historically determined and intent upon imparting its own knowledge and its own history" (Borgemeister 1977: 147). The concept of the museum is the subsumption of all objects under its own level of knowledge as the truth: whatever is in the museum is art. 

exhibition by appending the academic-type labels "Fig. 0", "Fig. 1", "Fig. 2" or "Fig. A" to the exhibits or even to individual passages in the chapter Section des Figures in the catalogue of the Eagle Museum in Düsseldorf. Closer scrutiny reveals this supposed specification to be just the opposite, given the arbitrariness of the assignment of labels, and thus illustrates the interchangeability and equal ranking of the labelled objects. Broodthaers underscored this point by appending to all the objects the negative inscription "This is not a work of art" and stating: “"This is not a work of art': the formula is a figure 0. Each exhibited item in Düsseldorf is a figure 1 or a figure 2. And each station in this museum falls under this rudimentary system" Broodthaers 1994: 128).

Broodthaers's comment confronted the viewer precisely at the place that first gave the object its legitimacy as a work of art, namely the museum. The irony of the plastic signs announcing "This is not a work of art" is to be understood in the context of the declared objective of the exhibition: an "analytical treatment of the concept of art" (Broodthaers 1972, I: 4). While usually labels serve to identify the exhibits by stating their titles, materials and sizes or by providing the museum's own descriptions and classifications of the works, now the only information provided is a negation of the status as a work of art. The negative labelling thus returns to the objects their identity and uniqueness taken away when they were elevated to the status of artworks in a museum, and breaks with the self-evident ascription of status as well as with the overall discursive basis on which this ascription rests. The objects once more become the things they originally were.

But back to the eagle: Oppitz shows that Broodthaers defuses the mythical power of the eagle by demonstrating the presence of this power among all conceivable eagles. $\mathrm{He}$ describes this mythoclastic effect, reinforced by the principle of the sequence and the resulting annulment of the hierarchy, as follows:

A curious double effect: by subjugating all of the exhibits to his overall intent, Broodthaers strips off their mythical surplus value. He liberates the eagle objects from their conventional overdetermination precisely by using them anew, as equally ranked tools of his experiment. (Oppitz 1972: 20)

Borgemeister describes this demythologisation as the reversal of all definitions and overdetermination of the eagle objects down to the "zero point" (Borgemeister 1987: 151) which for Broodthaers has the aim of liberating the objects: release from the determination of the encyclopaedic order of knowledge generally and of that of the museum in particular. The view of the objects is to be freed from the perception, considered self-evident, of the eagle as a symbolic creature, in particular as a power symbol, in order to direct a critical regard at the historicity and interest-guided use of that symbol. Broodthaers himself repeatedly uses the concept of a zero point in this connection: "It's easy to see that I wanted to neutralise the use value of the eagle symbol and reduce it to a zero value in order to introduce critical dimensions into the history and the use of this symbol" (Broodthaers 1972: 20).

As a final point in this interpretation of the Section des Figures we shall discuss Broodthaers's exhibited objects from the world of commodities and consumption. Notable about the eagle exhibition was its display not only of eagles from the world of art and eagle artefacts from natural history museums, but also everyday objects depicting eagles. Particularly the latter objects illustrated Broodthaers's method of 
deconstruction and demythologisation, as well as his Marxist stance in addressing the difference between the pure material value and the surplus value of the products. For Broodthaers the principle of the myth of commodities corresponded to the principle of the museum: the products assume qualities extending beyond their functionality and utility. At the same time, insight into the background of their production is suppressed. Like works of art, commodities seem to have a life of their own, detached from the context of their origin.

Broodthaers provokes the viewer by juxtaposing eagles in art and eagles in advertising - the seemingly liberated eagle in historical art and the unfree eagle in contemporary advertising, as it were. He explains that “覧...医 when it places thought within a frame of reference that can help the individual protect himself against the images and texts communicated by mass media and advertising, which shape our codes of behaviour and ideology" (Borgemeister 1987, 42: 145).

\section{Experiment 3: Completion by the viewer}

For Broodthaers, the viewer plays a central role in the execution of the experiment. The directors Hartan and Ruhrberg emphasized that "the exhibitions are made for the visitor" (Broodthaers 1972, II: 5). Broodthaers wanted to dissolve the traditional role of the viewer as that of a merely passive perceiver. The activity he demanded was the cognitive completion of the project by the public, who were to be encouraged to intellectually embrace works of art beyond merely consuming them. The recipient would then be integrated into the process by giving meaning, a process that would deprive both the artist and the museum of their authority. The displacement in authority would lead to the de-hierarchisation of given structures. The spatialtemporal sequence of the individual sections of the fictional museum and the integration of the role-playing shifted the emphasis from the object to the process. In this project, Broodthaers assumed the role not only of artist, but also of museum director, curator, art historian and collector. The viewer was charged with completing the work of art. The fictional museum sought no unequivocal and universally valid interpretation, nor any denotation, but rather a connotation, an ambiguity, which the viewer would decipher and complete in his or her own way. Accordingly, visitors' comments were recorded in the catalogue for The Eagle from the Oligocene to the Present, where the two directors - Hartan and Ruhrberg - explain in their introduction: "We invited the public to collaborate on our experiment. The second part of the catalogue therefore begins with comments from visitors to the exhibition" (Broodthaers 1972, II: 5). Broodthaers let the visitors have their own say and made them assume the role of an art historian or critic by publishing their intellectual contributions in the form of a commentary. For the first time, the Städtische Kunsthalle thus presented an exhibition catalogue in two parts, with the second part containing the public's comments following the opening. De-hierarchisation could be seen again in the selection of comments, which were published in no particular order and in uncensored form. Unqualified comments such as "Probably supposed to give the Chinese after World War III an overview of our present culture" (Broodthaers 1972, II: 8) were included as well as those obviously misunderstanding the point of the exhibition, such as "Informative! But why aren't the objects decorated or fitted with eagles, etc. not works of art? Who decides this?" (Broodthaers 1972, II: 9). Besides the large number of negative comments 
and those showing a misunderstanding, some positive remarks were also published: "The myth of the eagle is demystified by the myth of 'This is not a work of art'. An interesting exhibition - confusing + stimulating." (Broodthaers 1972, II: 11)

In the catalogue Broodthaers asks: "To what extent has information about contemporary art penetrated into the public's consciousness?" (Broodthaers 1972, I: 16) Provocatively directing this question at the public, he immediately gives the expected answer: "'This is not ... this is not a work of art" means nothing other than: "You, the public - how blind you are!"'(Broodthaers 1972, I: 16). Broodthaers seems not to have expected that the public would understand his project in terms of the concept of art and the idea of the eagle - which gave his museum the subtitle Département des Aigles and was visualised in the Section des Figures. On this point Harten

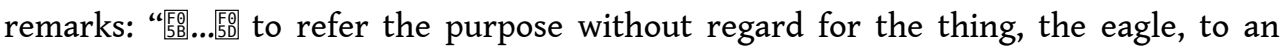
iconographic idea, means for Broodthaers to be blind" (Broodthaers 1972, II: 24). Broodthaers himself writes in retrospect in the second part of the catalogue about the results of his experimental exhibition: "The goal is to suggest a critical reflection on how art is presented in public. As regards perception by the public, I find that habits and personal fixations stand in the way of an unprejudiced reading. Nevertheless, the plaque bearing the inscription: 'This is not a work of art' plays a certain role. It disrupts the visitor's narcissistic projection onto the object he or she is viewing, but it does not reach their consciousness" (Broodthaers 1972, II: 19).

While the public's perception can be disrupted, the exhibition is unable to achieve a reflective result in terms of the idea of art and the idea of the eagle. The only remaining hope is therefore "that the viewer assumes the risk him or herself - for a moment - of no longer feeling so much at ease in his or her own senses" (Dickhoff 1994: 12).

\section{Conclusion}

Following Roland Barthes, we can characterise Broodthaers's Musée d'Art Moderne, Département des Aigles as a second-order myth (Broodthaers 1972, I: 16). His analysis of the concepts of art, the museum and the eagle aimed at their demythologisation. By utilising the structure of the museum, he integrated the myth of the museum in the artificial myth of his own museum. This artificial myth in particular helped him to uncover the quasi natural conditions of the museum as something historically evolved. The museum, whose construction historically depends on systems of classification, presents the latter as natural and unalterable givens. From behind the myth of the museum have emerged its social and political conditions, so that the museum could now be unmasked as the product of bourgeois ideology (Oppitz 1972: 177-180). This process is exemplified by the case of the eagle. In his Section des Figures Broodthaers exposed the Myth of the Eagle by producing in his museum an artificial myth. Through the constant repetition of this myth, in which Broodthaers stylised the eagle in all the forms of its overloaded significance in order to turn it into a sort of super eagle, he dissolved its ultra-meaning and reduced the object to what it actually is: an eagle. This enables us to perceive the apparent naturalness of the Eagle myth as historically conditioned. The second-order myth enabled him to overturn all definitions and overdetermination of the eagle objects.

Finally, at this point we can acknowledge the distinctly experimental character of Broodthaers's art, which explores the diverse definitions and possibilities of art on the 
levels of "the museum", "the exhibition" and "the viewer". He raised questions as to whether a museum or an exhibition could be a work of art, for example, leaving the answers up to the visitor. He thus focussed his artistic endeavours on the issue of how the museum participates in defining art and in establishing the status of works of art as fetish objects. With his experimental exhibition he attempted to free the work of art from its commodity value and the eagle from its overloaded symbolism, and to demythologise the creature. In this way artistic differs from scientific experimentation: Broodthaers's experiment did not involve controlled and purposive actions whose repetition would always yield the same results. Rather, such experiments were and are bound to a specific place and time, for the public's reactions will vary depending on when and where such artistic experiments occur.

\section{BIBLIOGRAPHY}

Broodthaers, Marcel. Marcel Broodthaers, Der Adler vom Oligozän bis heute. Vol. I and II. Exh. Cat. Düsseldorf: Kunsthalle Düsseldorf, 1972.

Broodthaers, Marcel. Marcel Broodthaers. Exh. Cat. Paris: Galerie nationale du Jeu de Paume, 1991. Broodthaers, Marcel. Marcel Broodthaers. Exh. Cat. Paris: Galerie nationale du Jeu de Paume, 1992. Broodthaers, Marcel. Marcel Broodthaers: Projections. Exh. Cat. Eindhoven: Stedelijk Van Abbemuseum, 1994.

Broodthaers, Marcel. Els Límits des Museum. Exh. Cat. Barcelona: Fundació Antoni Tàpies, 1995: 68-79.

Broodthaers, Marcel. Marcel Broodthaers. Cinéma. Exh. Cat. Düsseldorf/Berlin: Kunsthalle Düsseldorf/Nationalgalerie Berlin, 1997.

Broodthaers, Marcel. Marcel Broodthaers. Politique/Poetique. Exh. Cat. Wien: Kunsthalle Wien, 2003.

Broodthaers, Marcel. “Der Nullpunkt.” Heute Kunst Nº 1, April 1973: 20.

Barthes, Roland. Mythen des Alltags. Trans. Horst Brühmann. Frankfurt am Main: Suhrkamp, 2008.

Borgemeister, Rainer and Chris Cullens. "'Section des Figures' The Eagle from the Oligocene to the Present.” October Vol. 42, Autumn 1987: 135-154. DOI: 10.2307/778271

Borgemeister, Rainer. Marcel Broodthaers. Lesen und Sehen, Bonn: Weidle Verlag, 2003.

Buchloh, Benjamin H. D., Gilissen, Maria, eds. Marcel Broodthaers. Section Publicité du Musée d'Art Moderne, Département des Aigles. New York: Marian Goodman Gallery, 1995.

Crimp, Douglas. "Dies ist kein Kunstmuseum." Über die Ruinen des Museums. Dresden/Basel: Verlag der Künste, 1996. 212-241.

Dickhoff, Wilfried, ed., Marcel Broodthaers. Interviews \& Dialoge. Köln: Kiepenheuer \& Witsch, 1994.

Dinçkal, Noyan. "Wissenschaftsgeschichte." Handbuch Moderneforschung. Interdisziplinäre und internationale Perspektiven. Friedrich Jäger, Wolfgang Knöbl and Ute Schneider, eds. Stuttgart: Verlag J.B. Metzler, 2015. 
Dingler, Hugo. Das Experiment: sein Wesen und seine Geschichte. München: Mentis 1928.

Gombrich, Ernst. The Story of Art. London: Phaidon 1984.

König, Susanne. Marcel Broodthaers. Musée d'Art Moderne, Département des Aigles. Berlin: Reimer, 2012.

Malraux, André. "Das imaginäre Museum” in Stimme der Stille. Baden-Baden: Woldemar Klein Verlag, 1956.

Minges, Klaus. Das Sammlungswesen der frühen Neuzeit. Kriterien der Ordnung und Spezialisierung. Münster: Lit-Verlag, 1998.

Oppitz, Michael. “Adler Pfeife Urinoir.” Interfunktionen 9, Köln, 1972: 177-180.

Rheinberger, Hans-Jörg. “Experiment, Forschung, Kunst” Jahreskonferenz der Dramaturgischen Gesellschaft, Oldenburg, 26-29 April 2012. https://dg.websyntax.de/assets/Uploads/ ContentElements/Attachments/Hans-Joerg-Rheinberger-Experiment-Forschung-Kunst.pdf

Zwirner, Dorothea. Marcel Broodthaers. Köln: König, 1997. 116-139.

\section{NOTES}

1. See Borgemeister (1987); Borgemeister (2003: 137-192); Crimp (1996); Dickhoff (1994: 75-96); König (2012); Zwirner (1997: 116-139); Broodthaers (1991: 189-231) and Marcel Broodthaers: Projections (1994: 46-53, 78-87).

2. Interview with Jürgen Harten on $26^{\text {th }}$ May 2000.

\section{ABSTRACTS}

Experimentation is integral to literature and art as well as to the natural sciences. The search for new artistic means of expression, the formation of a new canon and the use of new artistic materials are all based on findings obtained through experimentation. Experimentation was a key category for the modernists in particular. The difference of modern art with previous periods lies especially with its having given a new programmatic significance to experimental procedures in both the natural sciences and art. Modern artists are characterised by a stylistic pluralism as an expression of a constantly changing society, accompanied by a new understanding of art. In particular, art after 1945 gave rise to a new concept of art hardly anticipated in the traditional genres of painting and sculpture, for example. Thus "experimentation" nowadays refers to controlled, purposive action aiming at some specific goal: the invention of something new or the production of new knowledge. This quest for the new characterises modern art and in particular contemporary art in a variety of ways. While controlled artistic practices may at first glance seem to conflict with the artist's claim to freedom, artists do indeed seek new practices that are repeatable and therefore controllable. Not everything that is contemporary is experimental. "Experimental" does not just refer to something new - experimental art rather comes from certain experimental methods. In his work Musée d'Art Moderne, Département des Aigles (1968-72) the Belgian artist and poet Marcel Broodthaers investigates a particular form of experimental 
art. Broodthaers' fictional museum project provides a good basis for a study of the concept, as the artist has himself repeatedly referred to the experimental quality of his art. Indeed, our starting assumption in this essay is that this work by Broodthaers illustrates in a paradigmatic way central elements of experimentation in contemporary art of the 1960s and 70s. For example, on 16 May 1972 Broodthaers opened a section of a museum entitled The Eagle from the Oligocene to the Present in the Städtischer Kunsthalle in Düsseldorf, signing it with the following words: "Marcel Broodthaers shows an experimental exhibition of his Musée d'Art Moderne, Département des Aigles, Section des Figures". The first part of this essay examines the experiment in which a museum with altogether twelve sections is declared to be a work of art. The second part then explicates the experiment in which an exhibition is declared to be a work of art. Finally, the third part examines the role of the viewer within Broodthaers' artistic experiment.

L'expérience fait partie intégrante des sciences naturelles, de la littérature et de l'art. La recherche de nouveaux moyens d'expression artistique, la création d'un nouveau canon ou l'utilisation de nouveaux matériaux artistiques, tout cela vient de découvertes accompagnées d'expériences. En particulier pour l'âge moderne, l'expérience est considérée comme une catégorie clé. La principale différence de l'art moderne par rapport aux époques précédentes est que dans la modernité, la signification programmatique des méthodes expérimentales dans les sciences naturelles et les arts a changé. La modernité a été marquée par le pluralisme stylistique comme expression d'une société en constante évolution et s'est accompagnée d'une nouvelle conception de l'art. Par-dessus tout, l'art d'après 1945 constitue un nouveau concept de l'art, qui ne correspond guère aux genres artistiques habituels tels que la peinture et la sculpture traditionnelles. À l'heure actuelle, l'expérience est considérée comme une action contrôlée et axée sur des buts avec un objectif principal: pour inventer de nouvelles choses ou générer de nouvelles idées. Cette quête de quelque chose de nouveau caractérise l'art moderne et surtout l'art contemporain à bien des égards. Tandis que les pratiques artistiques contrôlables semblent à première vue contredire la prétention artistique de liberté, les artistes recherchent aussi dans leurs œuvres des pratiques nouvelles, reproduisibles et donc maîtrisables. Cependant, tout ce qui est contemporain n'est pas nécessairement expérimental. Expérimental n'est pas un terme qui désigne quelque chose de nouveau en général, en revanche, l'art expérimental a été créé par certaines méthodes expérimentales. L'œuvre Musée d'Art Moderne, Département des Aigles (1968-1972) de l'artiste et poète belge Marcel Broodthaers explore une forme particulière d'art expérimental. Le projet de musée fictif de Broodthaers est un bon choix parce que l'artiste luimême s'est souvent référé à la qualité expérimentale de son art. En fait, selon l'hypothèse initiale de cet article, l'œuvre d'art de Broodthaers montre de façon paradigmatique des éléments centraux de l'expérience de l'art contemporain des années 60 et 70. Le 16 mai 1972, par exemple, Broodthaers ouvrit au Städtische Kunsthalle de Düsseldorf un département intitulé "Der Adler vom Oligozän" et le signa ainsi: "Marcel Broodthaers présente une exposition expérimentale de son Musée d'Art Moderne, Département des Aigles, Section des Figures". La première partie de cet essai examine l'expérience dans laquelle un musée de douze sections au total est déclaré œuvre d'art. Le second aborde ensuite l'expérience dans laquelle une exposition est déclarée œuvre d'art. Et la troisième examine le rôle du spectateur dans l'expérience artistique de Broodthaer.

\section{INDEX}

Mots-clés: art conceptuel, art contemporain, 1960 (années), 1970 (années), Broodthaers Marcel, critique institutionnelle, expérience artistique, rôle du spectateur

Keywords: artistic experiment, Broodthaers Marcel, concept art, contemporary art, 1960s, 1970s, institutional critique, role of the viewer 


\section{AUTHOR}

\section{SUSANNE KÖNIG}

Susanne König is Professor of Art History at the Fachhochschule Potsdam. Her current research focuses on the circulation of knowledge between art and design. Before that she was a member of the academic staff at the University of Leipzig, the University of Paderborn and the University of Siegen. She studied art history and philosophy at the University of Stuttgart as well as arts and media management at the Hanns Eisler School of Music in Berlin. She is the author of Marcel Broodthaers: The Musée d'Art Moderne, Département des Aigles, Reimer Verlag, Berlin, 2012. Contact: Koenig[at]fh-potsdam.de 